\title{
Ethonomics \& the History of Economic Thought
}

\author{
*Ahmad Jafari Samimi, Ahmad Chehreghani \\ University of Mazandaran, Babolsar, Iran \\ *jafarisa@umz.ac.ir
}

\begin{abstract}
The purpose of this paper is to survey the relationship between economics and ethics in the history of economic thought. So the descriptive methodology of research is applied to find study and analyze the references which have been written about the matter. The conclusion shows that economics not only hasn't been detached from ethics, but also has been the subdirectory of ethics in the beginning. In the other word economics grew out of moral philosophy and eventually became one of the moral sciences but these two sciences detached from each other as times go on, and this detachment is not part of the tradition of economics.
\end{abstract}

Keyword: Economics, ethics, ethical economics, engineering approach, history of economic thought.

\section{Introduction}

In the common economic theories, economics has been shown as a science that is irrelevant with ethics. There are not ethical considerations in the producer behavior and maximizing the profit, consumer behavior and maximizing utility, monopolist behavior, and price discrimination, pricing methods, international trade etc we studied in economic literatures. Based on the background and imagine of economics and ethics exists in the minds, "economical human" and "ethical human" seem to be in conflict with each other. Economics explains "material aspects" of human life, and ethics emphasizes "non-material aspects" of its. The economic concepts and ethical concepts seem to be in conflict together, or at least unrelated to each other. At first glance it seems that concepts such as rationality, profit, revenue etceteras cannot be collected with concepts such as fairness, sacrifice, justice etc.

We often hear that economists are like engineers. Just as the client expects the engineer to tell him what is possible, not what is desirable - how best to build a home on an unstable hillside, not whether to - the economist provides an understanding of what is obtainable within the constraints of the economy, not of what is desirable. It is up to "someone else" to choose; the economist lives to help that "someone else" to make an informed choice. Economists use this analogy and others like it (economist as physician) to make the point that economics is distinct from ethics (Yuengert, 2000, p. 4). Here we want to study the relationship between these two sciences.

\section{Literature Review}

Ethics is known as moral philosophy, is a branch if philosophy that addresses questions about morality- that is concepts such as good and evil, right and wrong, virtue and vice, justice and crime, etc. Major branches of ethics include:

Meta-ethics, about the theoretical meaning and reference of moral propositions and how their truth (if any) may be determined. Normative ethics, about the practical means of determining a moral course of action. Applied ethics, about how moral outcomes can be achieved in specific situations. Moral psychology, about how moral capacity or moral agency develops and what its nature is. Descriptive ethics, about what moral values people actually abide by.

Economics is a social science that analyzes and describes the consequences of choices made concerning scarce productive resources. Economics is the study of how individuals and societies choose to employ those resources: what goods and services will be produced, how they will be produced, and how they will be distributed among the members of society. These two sciences have been related together from their 
beginning. In fact economics has been the subdirectory of ethics in the beginning. But these two sciences detached from each other as times go on, and this detachment is not part of the tradition of economics.

Most of economics, who have written about the relationship between ethics and economics, indicates the fact of economics' being born of ethics. For instance the following can be named: Sen (1987) writes that "economics has had two rather different origins, both related to politics, but related in rather different ways, concerned respectively with 'ethics,' on the one hand, and with what may be called 'engineering,' on the other... The 'engineering' approach is characterized by being concerned with primarily logistic issues rather than with ultimate ends and such questions as what may foster 'the good of man' or 'how one should live. 'The ends are taken as fairly straightforwardly given, and the object of the exercise is to find the appropriate means to serve them.". He traces the ethics-related tradition to Aristotle, for whom, "[T]he study of economics, though related immediately to the pursuit of wealth, is at a deeper level linked up with other studies, involving the assessment and enhancement of more basic goals... Economics relates ultimately to the study of ethics." (P. 2-3)

Alvey (1999) sets out a brief history of economics as a moral science in the history of economic thought in four parts. First, he sketches the evolution of economics before Adam Smith, showing that it was generally conceived of as a part of moral philosophy. Second, he presents elements of the new interpretation of Smith, which show him as a developer of economics as a moral science. Third, he show that even after Smith, up to the beginning of the twentieth century, a number of leading economic theorists envisioned economics as a moral science, either in theory or in practice, and Fourth, he sketches the decline of economics as a moral science. Overall, he shows that the current view of the detachment of economics from morals is alien too much of the history of the discipline. He concludes that until Marshall, economics was related to ethics and attachment between them occurred in twentieth century.

Broome (1999) examines some of the practical issues that lie between economics and ethics, and shows how utility theory can contribute to ethics, as many economic problems are also ethical problems. He raises some fundamental questions about economic equality, preserving the environment, and the allocation of medical resources, and powerfully shows how economic methods can contribute to moral philosophy. Youngert (2000) surveys the relation between ethics and economics, and declares that the importance of ethics for economics can be made clearer and more compelling by returning to the classical conception of the relationship of ethics/prudence and the sciences. Ethics and economics are related hierarchically, not horizontally. Ethics is above economics; ethical reflection is prior to economic analysis, in the same way that consideration of ends is prior to consideration of means. Within this hierarchical relationship, both the limited autonomy and the value foundations of economics become clear.

Krishna and Wilber (2010) in their book provides an introduction to the relationship between economics and ethics, explaining why ethics enters economics, how ethics affects individual economic behavior and the interactions of individuals, and how ethics is important in evaluating the performance of economies and of economic policies. All of these works and the like study the relationship between ethics and economics in various aspects and commonly concluded that ethics and economics were related together in the beginning and economics was Subordinate to the ethics.

\section{Methodology}

The methodology of research in the paper is descriptive. Hence all of the books and papers which have written about the matter are studded and analyzed to answer these questions: Whether economics has been separated from ethics at its genesis? And have economists been alien to ethics in the past? If answer is "not", what are the reasons for rising of ethical economics in the recent decades? This paper will attempt to answer these questions. After a short above preface, in next section we study the relationship between economics and ethics in the history of economic thought. In order to, we divide the period of genesis of economics to the present into two periods: (a) Since Aristotle to the end of nineteenth century, (b) Since the beginning of the twentieth century until now. The reason of this division is that according to historical studies, it appears until the end of the nineteenth century the separation between ethics and Economics was not done strongly, and "until the early twentieth century it was taken for granted that all sciences [like economics] were subordinate 
to ethics." (Yuengert, 2000, p. 5), and clear separation between these two sciences as well as again considering to ethics in economics has been done in the twentieth century (Alvey, 1999, p. 1- 2).

\section{Discussion}

In this section that is main part of the paper, we study the position of ethics in economics in the history of economic thought. According to the explanation was mentioned in previous section, we review the first part of the history;

Since Aristotle to the end of nineteenth century: The antecedents of the theoretical connection between ethics and economics go back, at least, to Aristotle who conceived economics as a part of practical philosophy together with politics and ethics. At the beginning of his Nicomachean Ethics, Aristotle places economics in relation to human ends by referring to the specific purpose of economics as a set of methods or skills oriented to the objective of increasing wealth. On the contrary, Politics is considered to be the main art that one should use «for the rest of the sciences», including economics, since politics settles down what should and should not be done to reach the final objective of Politics, that is, the good for human happiness (Sen, 1987, p. 3; see also Encinar, Cendejas \& Muñoz, 2006, p. 5; Yuengert, 2000, p. 5;).

From about 1240 A.D., when Aristotle was rediscovered in Western Europe, the Scholastics used the Nichomachean Ethics as one of the leading textbooks and it was through this study of moral philosophy that Scholastic economics emerged: Scholastic economics was Aristotelian economics (Alvey, 1999, p. 5). The scholastics saw economics as a subordinate part of the broader theological/moral concerns. Scholasticism remained influential in European universities for centuries. In the European universities in the 1700s economics was taught as part of moral philosophy (Ibid, p. 26). Mercantilists lived from the fifteenth to the eighteenth centuries. Although Professor John Kent Galbraith claims that they were the point of detachment of economics from ethics (Galbraith, 1987, p. 37) but available evidences show that although they had an impact on this detachment, but economics was a part of philosophy until Smith's time.

Most of thinkers of the history of economic thought claim that Adam Smith was the commencer of detachment economics from ethics (e.g. Friedman \& Friedman, 1980, p. 19). They try to prove their claim by indicating on some parts and sentences of Wealth of Nations ${ }^{1}$. As history of economics say (e.g. Lux, 1990; Young, 1997), Adam Smith was a moral philosopher before he was economist. He became interested in economics without ceasing to be a moral philosopher (Alvey, 2000, p. 81). His prior book was Theory of Moral Sentiments which is about moralities. It isn't famous like Wealth of Nations, but proper understanding of Smith's Wealth of Nations requires a prior understanding of the Theory Moral Sentiments. Review of the lectures at the University of Glasgow of Francis Hutcheson (see Ross, 1995, p. 53), the teacher of Adam Smith and more exact study of two above books (see Kleer, 2000) shows that economics hasn't separated from ethics until (and in) smith's time.

The next classical economist after Smith was Thomas Malthus. He became "the first professional economist" and the first professor of political economy in England. He saw economics as a moral science, and explicitly followed in the tradition of Smith. While he was the dominant figure in political economy for a period, he soon was challenged by the emergence of David Ricardo (Alvey, 1999, p. 12). Ricardo saw economics as a technical rather than a moral subject (Ricardo, 1951/1973, vol 2, p. 338). In attention to the important battle between Malthus and Ricardo, what is concluded, is that Ricardo did not see economics as a moral science (Alvey, 1999, pp. 12-13). After Ricardo and Malthus, John Stuart Mill took over as the leading political economist. Mill does present us with a moral science of economics. Nevertheless, his moral science (especially given his formal methodology) is probably not as deep as Smith's (Ibid, p. 15, 17).

\footnotetext{
1 - For instance this famous sentence: "It is not from the benevolence of the butcher, the brewer, or the baker, that we expect our dinner, but from their regard to their own interest." (Smith, pp. 9-10).
} 
It seems that it was William Stanley Jevons who implied on necessity of turning political economy into modern economics which is an exact science and separated from ethical concerns (Jevons, 1888, p. 33). Alfred Marshall supported Jevons's call for the adoption of a new name for the discipline. For Marshall, economics is a "separate science" with pure and applied aspects (Marshall, 1920, chap. 3), and it is better described by the term 'Economics' than by the term 'Political Economy'. For him, the name change was part of a wider battle, namely, the independence of economics from the Moral Sciences Tripos (tripos are similar to what we would call majors). Although he opposed Jevons in many areas, Marshall argued that economics was actually more like the natural sciences (Alvey, 1999, p. 19, 21). The battles between Malthus and Ricardo, between Jevons and Mill, and between Marshall and Jevons, showed that the status of economics as a moral science was in flux. Towards the end of the nineteenth century, even with Marshall's missionary leadership, the mainstream of the discipline came under considerable criticism from humanists over the apparent lack of ethics in economics (Ibid, p. 23).

Economists of the nineteenth and early twentieth century did not separate economics from ethics as completely as economists today do, even though they increasingly separated ethical considerations from economics. They placed economic analysis within a context that gave it a high moral purpose (most evident in Marshall 1920), which embodied the awareness that economics was incomplete, and that economics must be at the service of a moral debate which took place on a higher level (Yuengert, 2000, p. 19). Nevertheless even after Smith, up to the beginning of the Twentieth century, a number of leading economic theorists conceived of economics as a moral science, either in theory or in practice (Alvey, 1999, p. 27). After this brief historical survey, the important question is that: why has economists' tendency to consider the role of ethics in economics risen again? In order to answer, we should know what happened in $20^{\text {th }}$ century.

From the early $20^{\text {th }}$ century until now: During the years of first quarter of twentieth century, yet there were some thinkers who are indicating the role of ethics in economics. One of the most famous of them was Max Weber. In his book, The Protestant Ethic and the Spirit of Capitalism (1904-1905) Weber indicated that the development of western countries were based on the morality which has been formed by intellectuals like "Calvin" and "Luther" in addition to moral foundations of Christianity. As we know, Weber died at a premature age; he was only 56 years old when he succumbed to pneumonia, and never had the time to finish a number of his projects. The Economic Ethics of the World Religions was, for example, never completed and Weber never got the time to write his sociology of culture (Swedberg, 1998, p. 535).

Until the 1920s, most economists held a consistent conception of the relation of ethics to economics. The relationship was hierarchical - economics is the science of wealth, and ethics (often referred to in classical terms as legislation or politics) makes use of the insights of economics and other social sciences (which are also subordinate to ethics) to make judgments about which courses of action are ethically desirable. Lionel Robbins's argument for a split between the positive and the normative was much more sweeping than what came before, and put a much greater distance between ethics and economics(see Robbins, 1935). Until Robbins (1935), economics was subordinate to ethics; economists might focus exclusively on "scientific" issues, but were aware that economics existed to serve ethics. Robbins put ethics and economics into separate universes (Encinar et al., 2006, p. 5), by identifying the normative-positive distinction with the factvalue distinction (see Blaug, 1992, p. 76-80, 130). By placing a "gulf" between economics and ethics, Robbins discards the previous, hierarchical relationship in favor of a fully autonomous economics, whose conclusions need not bear on ethical issues. According to Robbins, the economist must leave economics proper, and enter into a discourse which draws upon the insights of history, political philosophy, law, economics, and fine arts, but not ethics (Yuengert, 2000, pp. 20-22).

Positivistic methodological works of Robbins (1935) did influence the profession. Robbins's approach to positive economics defined interpersonal comparisons of satisfaction as subjective and thus outside of the realm of economic science; this had a major negative effect not merely on welfare economics, but when aggregated on the whole character of economics as a moral science (Alvey, 1999, P. 23, 24). After that tendency to separate economics from ethics and strong methodological tendency towards positivism in the economics propounded increasingly, at first in theory, then in practice. As we see this approach continues to the present-day, and yet has retained its followings. On the other hand mathematics came to be used arrogantly in economics. Econometrics has emerged as an integral part of most Ph.D. dissertations in 
economics. The Nobel Prize winner, Frisch, was one of those who took up the statistical task given by Jevons. New mathematically-based sub-disciplines of information economics and game theory have emerged, whereas economic history and the history of economic thought have been squeezed out (Ibid, pp. 24, 25). The result was formation the mistake opinion that economics was about logic. So the approach that Amartya Sen entitles: "engineering approach", became prevalent. As Sen says "This approach is characterized by being concerned with primarily logistic issues rather than with ultimate ends and such questions as what may foster 'the good of man' or 'how should one live'” (Sen, 1987, p. 4).

There were two major reasons why economics has become detached from moral concerns. First, the natural sciences came to be seen as successful and the attempt was made to emulate that success in economics by applying the natural science methods, including mathematics, to economic phenomena. Second, the selfstyled economic science came to adopt positivism, which ruled out moral issues from science itself (Alvey, 1999, p. 2). During these years of twentieth century economics wear a "coat of engine", but this process hadn't gracious results as was expected, and as Sen says "the nature of modern economics has been substantially impoverished by the distance that has grown between economics and ethics."(1987, p.7), and soon economists saw that the way which they picked out was false. Some environmental and social problems occurred. Many economists (and authors of other human sciences) became increasingly concerned with issues related to the environment, and these issues became of prime importance in their frameworks. They began to write books and articles that deal with the ecological and environmental issues and other issues that relate to the environmental challenge, such as technological change (e.g. Heilbroner, 1950; see also Kapp, 1950; Lowe, 1935). The attempts to solve the problems have resulted in a set of theoretical results on the frontier between economic theory and ethics (Encinar et al., 2006, p. 4).

So far we can say that first cause of coming back of ethics to economics' world is engineering economics' failure in solving the problems of countries. According to the historical review that was mentioned, we can divide the economists' tendency to ethics, in the years of twentieth century until now--especially in the field of development economics-- to the following three period ${ }^{1}$ : First period covers the years of $1950-1970$ in which thinkers and theorists mainly reacted to the lack of prosperity of engineering economics, and environmental and human disasters of mechanical approaches to development economics. Economists began to explore the relationship between economics and the environment. They reviewed history of economic thought and methodology, and produced analyses of environmental problems (e.g. Boulding, 1966; Heilbroner, 1950; Kapp, 1950, 1961, 1963, 1970a, 1970b; Kneese, 1962) and analyses of ethical approach of economics were started by economists (e.g. Alexander, 1967; Buchanan, 1964, 1965; Lowe, 1967). Adam Smith's The Theory of Moral Sentiments and his ethical opinions became considerable for some economists and authors that were writing about economic problems of counties that have occurred because of economics' lack of ethics consideration (e.g. Boulding, 1969; Macfie, 1961).

Gunnar Myrdal's brilliant book Objectivity in Social Research is one of the most important works that are placed in this period. He believes that the most fundamental methodological issue that social scientists face is that what is objectivity? And how can a researcher in the process of trying to understand the realities, and relations among them achieve to objectivity, and avoiding prejudice, how could he analyze problems and attempt to solve them (Myrdal, 1969, pp. 10-25). In the other word Myrdal's meant and other similar works is that social realities are related with types of complex ethical and moral affairs. Therefore in order to analyze and solve problems, researchers should recognize the ethical concerns of phenomenon that are different in a country from another's. So a same economic policy-making isn't successful in all of countries. Considering peoples' ethical beliefs--that are an integral part of their lives--is important factor in success to apply economic theories in different countries. According to the factors which was noted in Myrdal's statements, and ignoring them by engineering approach in practice, we can say the second cause of economists' again considering to ethics was deep ponder in the social and human sciences especially in economics that finally its result was necessity of considering the ethical concerns. This deep thinking created after the failure of engineering economics to solve the economic problems in different countries.

\footnotetext{
${ }^{1}$ - The Division has been adapted from: Jayal (1997), "Environment and Development in the Age of Neoliberalism". Man and Development, 11(3).
} 
The second period includes the years of 1970-1990 that involves a process that finally lead to presentation of the "theory of capabilities" by Amartya Sen, in which, applying aspects of ethical considerations are provided in development programs (Pettit, 2001; see also Alexander, 2007; Nussbaum, 2003). Undoubtedly Amartys Sen, the surprising winner in 1998 of the Nobel Prize for Economics is one of the most prominent economists who have worked about ethical economics for years, His work should be mentioned in this period; in his book On Ethics and Economics Sen (1987) argues that a closer contact between welfare economics and modern ethical studies that can substantively enrich and benefit both disciplines. Attending to social interdependence and internal tensions within consequentialist reasoning, he proves concept of rationality of behavior. Sen also studies some related topics; the misinterpretation of Adam Smith's views on the role of self-interest (see chap. 1); the plausibility of an objectivist approach that attaches importance to subjective evaluations; and the admissibility of incompleteness and of "inconsistencies" in the form of over completeness in rational evaluation (see chap. 2). He also explores the role and importance of freedom in assessing well-being as well as choice (see chap. 3). Sen's contributions to economics and ethics have greatly strengthened the theoretical bases of both disciplines.

John Rawls' book $A$ Theory of Justice was very effective on the more attention to ethics in this period. He expressed a necessary part of the Joint kernel of the democratic tradition--justice as fairness--and provided an alternative to utilitarianism, which had dominated since the nineteenth century. The relation between economics and ethics in the history of economic thought and considering the role of ethics in various areas of economics was met with a more welcoming (e.g. Buchanan, 1984, 1985, 1987, 1988; Langholm, 1979; Wilbur, 1986). One way of restoring a place for ethics in the curriculum is to include a segment on Adam Smith's Theory of Moral Sentiments and other economic theorists who develop economics along the moral tradition (Alvey, 1999, p. 2). So writing about Adam Smith's moral beliefs and analyze his books and lectures continued over the previous period (e.g. Heilbroner, 1973; Hollander, 1977; Kleer, 1995; Coase, 1976; Evensky, 1989).

Introducing the combination of economic doctrine of new Kant's philosophical system and ethics of John Rawls, economic development was considered as a process that leading to increase human capabilities and follow its aims relying on free choice of people. Thus variables such as voting, education, information, public participation, and equal dignity. . . is considered as rights among the public, and finally the second period leads to the a process that publication of Human Development Report in the early of 1990 can be considered as its departure point. The third period started in early 1990 and has continued until now, emphasizing on the achievements of the previous steps and relying on them, tries to reconcile systems of abstract economic theories with practical real world and practical economic issues and an attitude is developed that umlaut ethical and technical considerations with each other in economics. Despite the tendency of some economists to reject economics as a moral science, there were a number of economists who sought to maintain it in the moral tradition. In the list we would include the well-known authors such as Keynes, Boulding, and Sen, and the little-known, recent writers such as Young and Temple Smith (Alvey, 1999, p. 26). Anyway we see that supporters of considering to ethical economics and a number of the books and articles have written about the matter have risen in this period (e.g. Brooke, 1991; Blaug, 1998; Buchanan, 1994; Coates, 1996; Crocker, 1991; Crespo, 1998; Griffiths \& Lucas, 1996; Hausman \& McPherson, 1996; Mc Closkey, 2006; Oslington, 2003; Sen, 2009; Temple-Smith, 1997; Vickers, 1997; Waterman, 2002; Young, 1997).

Samuels (1998) has done the similar work of Myrdal in this period. Despite of some differences between the works, both Myrdal and Samuels conclude that economists should explicitly recognize and declare the ethical basis for their models. Such full disclosure is particularly important in light of the fact that economists must often formulate these ethical goals themselves, since no one will provide them - there is no master whom they serve (Alvey, 1999, p. 26). Further study on Smith in recent decades has shown how economic analysis of the Wealth of Nations as part of a carefully constructed system, including ethics, jurisprudence and philosophy of science. This interesting finding makes the analysis of Smith's life and works to be welcomed much. An increase the number of books and articles has been written about it in recent decades confirms this fact (e.g. Alvey, 1994, 1996, 1997, 1998a, 1998b, 2001, 2003a, 2003b; Clarke, 2000, 2002; Fitzgibbons, 1995; Fitzgibbons, 1995; Fleischacker, 1991, 1996, 2004; Haakonssen, 1981; Hill, 2001; Kleer, 2000; Lux, 1990; Rothschild, 2001; Skinner, 1996; Werhane, 2006; Winch, 1996). 
After financial crisis of 2008, economists' attention on the ethical and theological foundations of economics increased more than previous (e.g. Mayer, 2009), and writing about smith has continued (e.g. Blaug, 2008; Brewer, 2009; Long, 2009; McCloskey, 2008; Oslington, 2010; Samuels, 2009). On the other hand considering to methodology of economics continued in this period (e.g. Backhouse, 1994; Blaug, 1992). However, considering to the ethical economics is growing. It seems that according to a series of theoretical and practical considerations, ethical economics has a higher position in the future. In the field of theory, growing understanding of frustration of positivistic approach to economics, and increasing importance of interdisciplinary approach to science, emphasize on the need for attention to ethics in economics. In the practical field, problems like phenomenon of environmental crisis on a global scale which has occurred because of engineering and Mechanical approach to economics shows ethics should be placed in economics.

\section{Conclusion}

After the introductory remarks we posed the question: what are the reasons for rising of ethical economics in the recent decades? Then we briefly reviewed the position of ethics in the history of economic thought. Historical results of the review showed that economics grew out of moral philosophy and eventually became one of the moral sciences but later these two sciences separated from each other, and this detachment is not part of the tradition of economics. With a short overview of environmental problems and works of Sen and Rawls on the one hand and Myrdal and Samuels on the other hand, we found two major answers for the above question: First the failure of mechanical and engineering approach to economics in solving the economic and social problems of countries such as environmental problems, and the second, deep ponder in the humanities and social sciences that was created following of the failure of positivistic approach to science, especially in economics.

\section{References}

Alexander, J. (2007). Republican Freedom and Amartya Sen's Theory of Capabilities. Paper presented at the Human Development and Capability Association conference Ideas Changing History, 17 - 20 September, New School, New York.

Alexander, S. S. (1967). Human Values and Economists. In S. Hook (Ed.), Human Values and Economic Policy. New York: New York University Press.

Alvey, J. E. (1994). Adam Smith's Mistake, Review of Adam Smith's Mistake by Kenneth Lux. History of Economics Review , 21, 105-6.

Alvey, J. E. (1996). A New Adam Smith Problem: The Teleological Basis of Commercial Society, PhD dissertation, University of Toronto. A revised version will be published shortly by Ashgate.

Alvey, J. E. (1997). Postmodern 'Readings' of Adam Smith's 'Discourse'. History of Economics Review, 26,15566.

Alvey, J. E. (1998). Adam Smith's Higher Vision of Capitalism. Journal of Economic Issues, 32(2), 441-8.

Alvey, J. E. (1999). An Introduction to Economics as a Science. Working paper 15. Independent Institute. www.independent.org/pdf/working_papers/15_introduction. pdf (accessed 13 November 2009).

Alvey, J. E. (2001). Adam Smith's Moral Science of Economics. History of Economics Review, 33, 81-95.

Alvey, J. E. (2003a). Adam Smith: Optimist or Pessimist? Aldershot: Ashgate.

Alvey, J. E. (2003b). Adam Smith's Teleological, or proto-Hegelian, View of History. Language, Information, Text, 10, 23-40.

Backhouse, R. (1994). New Directions in Economic Methodology. London: Routledge.

Blaug, M. (1992). The Methodology of Economics: Or How Economists Explain. Cambridge: Cambridge University Press.

Blaug, M. (1998). The Positive-Normative Distinction. In B. J. Davis (Ed.), The Handbook of Economic Methodology. Cheltenham: Edward Elgar.

Blaug, M. (2008), Invisible Hand. In S. Durlaf \& L. Blume (Ed.), The New Palgrave Dictionary of Economics. London: Palgrave Macmillan.

Boulding, K. E. (1966). The economics of the coming spaceship earth. In H. Jarrett (Ed.), Environmental quality in a growing economy. Baltimore: John Hopkins University Press.

Boulding, K. E. (1969). Economics as a Moral Science. American Economic Review, 59(1), 1-12. 
Brewer, A. (2009). On the Other (Invisible) Hand. History of Political Economy, 41(3), 519-43.

Brooke, J. H. (1991). Science and Religion. Cambridge: Cambridge University Press.

Broome, J. (1999), Ethics out of Economics, Cambridge: Cambridge University Press.

Buchanan, J. M. (1964). What Should Economists Do? Southern Economic Journal, 30 (3), 312-22.

Buchanan, J. M. (1965). Ethical Rules, Expected Values, and Large Numbers. Ethics, 76 (1), 1-13.

Buchanan, J. M. (1984). The Ethical Limits of Taxation. Scandinavian Journal of Economics, 86 (2), 102-14.

Buchanan, J. M. (1987). The Ethics of Debt Default. In J. M. Buchanan, C. K. Rowley \& R. Tollison (Eds.), Deficits. Oxford: Basil Blackwell.

Buchanan, J. M. (1988). The Ethics of Work. Scholar and Educator, 12 (1), 48-51.

Buchanan, J. M. (1994). Ethics and Economic Progress. Norman: University of Oklahoma Press.

Buchanan, M. (1985). Political Economy and Social Philosophy. In P. Koslowski (Ed.), Economics and Philosophy. Tübingen.

Clarke, P. H. (2000). Adam Smith, Stoicism and Religion in the Eighteenth Century. History of the Human Sciences, 13(4), 49-72.

Clarke, P. H. (2002). Unity in the Influences on Adam Smith. History of Economics Review, 36, 10- 25.

Coase, R. H. (1976). Adam Smith's View of Man. Journal of Law and Economics, 19, 529-46.

Coates, A. W. (1996). Utilitarianism, Oxford Idealism and Cambridge Economics. In P. Groenewegen (Ed.), Economics and Ethics. London: Routledge.

Crespo, R. F. (1998). Is Economics a Moral Science? Journal of Markets and Morality, 1(2), 201-211.

Crocker, D. A. (1991). Twards Development Ethics. World Development, 19 (5).

Dutt, A. K. \& Wilber, C. (2010). Economics and ethics. An introduction, New York: Palgrave-Macmillan.

Encinar, M. I., Cendejas, J. L. \& Muñoz, F. F. (2006). On the relationship between Ethics and Economics. Cuadernos de Economía, 29, 003-028.

Evensky, J. (1989). The Evolution of Adam Smith's Views on Political Economy. History of Political Economy, $21,123-45$.

Fitzgibbons, A. (1995). Adam Smith's System of Liberty, Wealth, and Virtue. Oxford: Clarendon Press.

Fleischacker, S. (1991). Philosophy in Moral Practice: Kant and Adam Smith. Kant Studien, 82(3), 249-269.

Fleischacker, S. (1996). Kant's Response to the Wealth of Nations. History of Political Thought, 17(3), 379-407.

Fleischacker, S. (2004). On Adam Smith's Wealth of Nations: A Philosophical Companion. Princeton: Princeton University Press.

Friedman, M. \& Friedman, R. (1980). Free to Choose. Penguin: Harmondsworth.

Galbraith, J. K. (1987). A History of Economics. London: Hamish Hamilton.

Griffiths, M. R. \& Lucas, J. R. (1996). Ethical economics. Houndmills Basingstoke, UK: Macmillan Press Ltd.

Haakonssen, K. (1981). The Science of a Legislator: The Natural Jurisprudence of David Hume and Adam Smith. Cambridge: Cambridge University Press.

Hausman, D. M. \& McPherson, M. S. (1996). Economic Analysis and Moral Philosophy. Cambridge: Cambridge University Press.

Heilbroner, R. (1950). What Goes Up the Chimney. Harper's.

Heilbroner, R. (1973). The Paradox of Progress: Decline and Decay in the Wealth of Nations. Journal of the History of Ideas, 34, 243-62.

Hill, L. (2001). The Hidden Theology of Adam Smith. European Journal of the History of Economic Thought, 8(1),1-29.

Hollander, S. (1977). Adam Smith and the Self-Interest Axiom. Journal of Law and Economics, 20(1), 133-152. Jayal, N. G. (1997). Environment and Development in the Age of Neoliberalism. Man and Development, 11(3).

Jevons, W. S. (1888). The Theory of political economy (3th ed). London: Macmillan and Co

Kapp, K. W. (1950). The Social Costs of Private Enterprise. New York: Shocken.

Kapp, K. W. (1961). Toward a science of Man in Society: A Positive Approach to the Integration of Social Knowledge, The Hague: Martinus Nijhoff.

Kapp, K. W. (1970a). Environmental disruption and social costs: Challenge to economics. Kyklos, 23(4).

Kapp, K. W. (1970b). Environmental disruption: General issues and methodological problems. Social Science Information, 9(4).

Kapp, K. W., \& Kapp, L. L. (1963). History of economic Thought: A Book of Reading. New York: Barnes and Noble.

Kleer, R. A. (1995). Final Causes in Adam Smith's Theory of Moral Sentiments. Journal of History of Philosophy, $33,275-300$. 
Kleer, R. A. (2000). The Role of Teleology in Adam Smith's Wealth of Nations. History of Economics Review, 31, 14-29.

Kneese, A. V. (1962). Water pollution: economic aspects and research needs. Washington, DC: Resources for the Future.

Langholm, O. (1979). Price and Value in the Aristotelian Tradition. Bergen: Universitetsforlaget.

Long, B. (2009). Adam Smith's Theism. In J. Young (Ed.), Elgar Companion to Adam Smith. Cheltenham: Elgar.

Lowe, A. (1935). Economics and Sociology. London: George Allen \& Unwin.

Lowe, A. (1967). The Normative Roots of Economic Value. In S. Hook (Ed.), Human Values and Economic Policy. New York: New York University Press.

Lux, K. (1990). Adam Smith's Mistake: How a Moral Philosopher Invented Economics and Ended Morality. Boston: Shambhala.

Macfie, A. L. (1961). Adam Smith's Theory of Moral Sentiments. Scottish Journal of Political Economy, 8(1), 1227.

Marshall, A. (1920). Principles of Economics (8th ed). London: Macmillan.

Mayer, T. (2009). Honesty and Integrity in Economics. Working Papers 09-2, University of California at Davis, Department of Economics.

McCloskey, D. (2006). Bourgeois Virtues: Ethics for an Age of Commerce. Chicago: University of Chicago Press.

McCloskey, D. (2008). Adam Smith, the Last of the Former Virtue Ethicists. History of Political Economy, 40(1), 43-71.

Myrdal, G. (1969). Objectivity in Social Research. New York: Pantheon books.

Nussbaum, M. (2003). Capabilities as Fundamental Entitlements: Sen and Social Justice. Feminist Economics, 9(2-3), 33-59.

Oslington, P. (2003). Economics and Religion. Cheltenham: Edward Elgar.

Oslington, P. E. (2010). Adam Smith as Theologian. London: Routledge.

Pettit, P. (2001). Capability and Freedom: A Defence of Sen. Economics and Philosophy, 17(1), 1-20.

Rawls, J. (1971). A Theory of Justice. Cambridge, Mass: Harvard University Press.

Ricardo, D. (1951/1973). The Works and Correspondence of David Ricardo (P. Staffa \& M.H. Dobb, Eds.), 1. Cambridge, U.K: Cambridge University Press.

Robbins, L. (1935). An essay on the Nature and Significance of Economic Science (2nd ed). London: Macmillan.

Ross, I. S. (1995). The Life of Adam Smith. Oxford: Clarendon Press.

Rothschild, E. (2001). Economic Sentiments: Adam Smith, Condorcet and the Enlightenment. Harvard: Harvard University Press.

Samuels, W. (2009). The Invisible Hand. In J. Young (Ed.), Elgar Companion to Adam Smith. Cheltenham: Elgar.

Samuels, W. J. (1998). The Methodology of Economics and the Case for Policy Diffidence and Restraint. In D. L. Prychitko (Ed.), Why Economists Disagree: An Introduction to Alternative Schools of Thought. Albany: State University of New York Press.

Sen, A, K. (1987). On Ethics and Economic. Oxford: Basil Blackwell.

Sen, A. (2009). The Idea of Justice. London: Penguin Books.

Skinner, A. S. Ed. (1996). A System of Social Science: Papers Relating to Adam Smith. Oxford: Clarendon Press.

Smith, A. (1776/2007). An inquiry into the nature and causes of the wealth of nations. Hampshire: Harriman House.

Swedberg, R. (1998). Max Weber's Vision of Economic Sociology. Journal of Socio-Economics, 27(4), 535-555.

Temple-Smith, R. (1997). Moral foundations of a nation's wealth: Adam Smith in the classroom. Paper presented at the Fifth Annual Teaching Economics Conference, 3-4 July, Toowoomba, Australia.

Vickers, D. (1997). Economics and Ethics: An Introduction to Theory, Institutions, and Policy. London: Praeger.

Waterman, A. M. C. (2002). Economics as Theology. Southern Economic Journal, 68, 907-21.

Werhane, P. H. (2006). Adam Smith's Legacy for Ethics and Economics. Tijdschrift voor Economie en Management: LI(2), 199-212.

Wilbur, C. K. \& Hoksbergen R. (1986). Ethical Values and Economic Theory: A Survey. Religious Studies Review, 12, 208- 214.

Winch, D. (1996). Riches and Poverty: An Intellectual History of Political Economy in Britain, 1750-1834 .Cambridge: Cambridge University Press. 
Young, J. T. (1997). Economics as a Moral Science: The Political Economy of Adam Smith. Cheltenham: Edward Elgar.

Yuengert, A. M. (2000). The Positive-Normative Distinction before the Fact-Value Distinction, Pepperdine University. 